Ethiopian Journal of Environmental Studies \& Management 8(4): 364 - 376, 2015.

ISSN:1998-0507

doi: http://dx.doi.org/10.4314/ejesm.v8i4.2

Submitted: January 24, 2015

Accepted: April 16, 2015

\title{
UNDERSTANDING CLIMATE CHANGE AND MANIFESTATION OF ITS DRIVEN IMPACTS IN THE SEMI ARID AREAS OF DODOMA REGION, TANZANIA
}

\author{
${ }^{*}$ MAYAYA, H.K., ${ }^{1}$ OPATA, G. ${ }^{2}$ AND KIPKORIR, E.C. ${ }^{2}$ \\ ${ }^{1}$ Institute of Rural Development Planning, P.O. Box 138, Dodoma, Tanzania \\ ${ }^{2}$ University of Eldoret, P. O. Box 1125-30100, Eldoret, Kenya
}

\begin{abstract}
This article examines the nature and manifestation of climate change driven impacts on the agrarian districts of Kongwa and Bahi in the semi arid areas of Dodoma region in Tanzania. A Survey of 398 households in the study area was undertaken to elicit information on the nature and manifestation of climate change driven impacts. Household and key informant interviews and focus group discussion were used in collection of primary data. Secondary data were obtained through documentary review and from the Tanzania Meteorological Agency for the case of climatic data. The results indicate that climate change in Dodoma region is evident as revealed by steady increase in temperature and wind speed and the general declining rainfall trend overtime. Consequently, such changes in weather parameters over time has severely affected the livelihoods of local communities as manifested through decline in crop production, loss of livelihood sources, shortage of water and pasture for livestock, and difficulties in feeding household members overtime among others. Given the findings, this article concludes that climate change and its impacts in the area are real and hence climate change interventions should focus on increasing agricultural productivity, pasture for livestock through sustainable livestock keeping and land use planning, diversification of socio-economic activities, as well as sustainable utilization and management of natural resources.
\end{abstract}

Keywords: Climate change; manifestation; local communities; semi arid areas, climate change impacts.

\section{Introduction}

Climate change as a global environmental challenge has caused impacts on natural and human systems across the world (IPCC, 2014). At its worst case, climate change interferes with human livelihood opportunities and economic development at large (Koch et al., 2007). The impacts of climate change are more severe in less developed countries (LDCs) whose economies depend on rainfed agriculture, pastoralism and forestry (World Bank, 2010). In this regard, climatic variations negatively impact agricultural activities, human health and other livelihood sources (IPCC, 2014).

In Tanzania, different regions and sectors suffer severely due to the persistent variability in rainfall and temperature (URT, 2006; URT, 2008). Among the consequences associated with climate change in Tanzania include melting of

*Corresponding Author: Mayaya, H.K.

Email: hznmayaya@yahoo.com 
glacier, the rise of sea level, food insecurity, water shortage, loss of biodiversity, loss of pasture, and drop of water levels in major rivers, lakes and reservoirs (NIDOS, 2009). For instance, due to reduced rainfall amount and increased variability in rainfall, the average yield of maize countrywide has decreased by 33 percent (URT, 2006). This creates challenges in supporting the population that is generally on the increase countrywide (URT, 2013).

In the semi arid areas of Tanzania where majority of rural residents depend on natural resources for livelihoods, the problem is even more challenging. Experiences from other semi arid areas in Tanzania indicate that climate change and variability has severely affected the livelihood of livestock keepers and crop farmers (Sewando and Yohana, 2012; Afifi et al., 2014). Given the fact that Dodoma region is a semi arid area, its ecosystem is very fragile and more susceptible to climate changes impacts.

So far, different efforts with different options in addressing the problem of climate change particularly in developing countries have been in place. However, most of the past solutions to address climate change challenges are rather reactive than proactive and their sustainability are questionable (Mearns and Andrew, 2010). In addition, the international and government capacity to effectively implement adaptation and mitigation measures in terms of financial, technical and human capacity is inadequate and sometimes lacks political will (Global Humanitarian Forum, 2009; World Bank, 2010). In this regard, some studies calls for finding local solutions to climate change impacts as such impacts are local and mostly felt by the local communities (Measham et al., 2011). This is due to the absence of a single approach in reducing climate change related risks across all settings, hence making climate change adaptation both place and context specific (IPCC, 2014).

According to IPCC (2014), decision making is critical in responding to climate related risks. Therefore, a need for informed decision is paramount in addressing the problem of climate change effectively. As noted by the Word Bank (2010), it is important to "act now, act together and act differently" since climate change is no longer a myth but real. However, to act properly requires information upon which interventions can be based and therefore a need for understanding the nature and manifestation of climate change driven impacts. This is in the view of unearthing critical information for planning and developing climate smart solutions. This article analyses information on meteorological changes and the manifestation of climate change driven impacts in semi arid areas of Dodoma region in Tanzania. This is to generate information necessary for making informed decisions on the planning, designing and implementation of intervention measures to climate change challenges in the area.

\section{Materials and Methods}

\section{The Study Area}

Dodoma region is located in the central part of Tanzania at latitude $6^{\circ} 10^{\prime} 23^{\prime \prime} \mathrm{S}$ and longitude $35^{\circ} 44^{\prime} 31^{\prime \prime} \mathrm{E}$. It is the region with an area of $41,310 \mathrm{~km}^{2}, \quad 2,083,588$ inhabitants and a total of 453,844 households (census of August 2012). This region is bordered by four other regions: Manyara in the North, Morogoro in the East, Iringa in the South and Singida in the West. Administratively, the region is subdivided into seven districts namely Dodoma municipality, Kongwa, Bahi, Mpwapwa, Kondoa, Chamwino and Chemba (URT, 2010a; URT, 2013). 
The climatic condition of Dodoma region is predominantly characterized by long dry season (late April- early December) and short wet season with an average rainfall of $570 \mathrm{~mm}$ of which almost 85 percent falls between December and April. The average maximum and minimum temperature are $31^{\circ} \mathrm{C}$ and $18^{\circ} \mathrm{C}$ respectively (URT, 2010a). Based on the climatic conditions above, Dodoma region is an arid and semi arid area particularly in its eastern and central part respectively (URT, 2006). In addition, the major economic activities for rural residents in the area are agriculture and livestock keeping both of which are rainfall dependent.

\section{Data Collection and Analysis}

A survey was undertaken to 398 respondents from the study area using a cross sectional research design that involves collecting data at a single point in time without repetition from the target population. A number of research methods such as interview, Focus Group Discussion (FGD) and review of various documents were used in data collection. In terms of sampling, probability sampling was used in sampling households who were the unit of analysis. On the other hand, non probability in particular purposive sampling was used to sample specific groups of respondents such as government officials and other interested stakeholders. In addition, two districts namely Kongwa and Bahi were purposively selected so as to establish a trend on matters pertaining to climate change impacts, adaptation and mitigation strategies as the two districts are severely affected by climate change extreme events such as drought, floods and rainfall variability (URT, 2006 and 2010b).

Regarding data analysis, qualitative data were analysed using qualitative content analysis that consists of analysing the content of documentary and verbal materials (Kothari, 2004). On the other hand, quantitative data were analysed using Statistical Packages for Social Sciences (SPSS) version 16 whereby frequencies and chi-square of independence values regarding the subject matter were computed. The effect sizes for the chisquare test of independence were determined by Phi and Cramer's V coefficients.

Meteorological data for the period from 1980 to 2011 obtained from Tanzania Meteorological Agency (TMA) for rainfall, temperature and wind speed for Dodoma region were also analysed using time series analysis (Mudelsee, 2010; Witt, 2013) to compliment the views of the local community on the climatic trends. Prior to analysis the anomalies of actual climatic data for rainfall, temperature and wind speed were normalised (Tesso et al., 2012). Thereafter, the normalised data were subject to the XY scatter plot in MS Excel 2007 programme that produced linear trend lines and equations indicating rainfall, temperature and wind speed trends for Dodoma region.

\section{Results and Discussion \\ Climatic related changes in Dodoma Region}

Prior to understanding of climate change manifestations on the livelihood of the agrarian communities in Dodoma region, respondents were asked to identify climatic related changes they have witnessed in the past ten years. The major climatic related changes noticed in the area include decrease in rainfall, unpredictable rainfall and droughts. Other changes noticed were temperature increase, more intense storm, temperature decrease and floods (Table 1). 
Table 1: Climatic changes witnessed by local community $(\mathrm{n}=398)$

\begin{tabular}{lll}
\hline Changes witnessed & $\mathrm{N}$ & Percent* \\
\hline Decrease in rainfall & 360 & 90.5 \\
Unpredictable rainfall & 302 & 75.9 \\
Droughts & 246 & 62.6 \\
Temperature increase & 185 & 46.5 \\
More intense storms & 103 & 25.9 \\
Temperature decrease & 74 & 18.6 \\
Floods & 53 & 13.3 \\
\hline
\end{tabular}

* Dataset based on multiple responses

In ascertaining the results from the local community, the analysis of meteorological data for Dodoma region in the past thirty years showed a similar trend whereby rainfall amount showed a declining trend while both temperature and wind speed showed an increasing trends (Figure 1 - 6). These findings are similar to the experience from other places in Africa and elsewhere as a result of climate change whereby variable rainfall pattern (Mongi et al., 2010; Okoba et al., 2011; Tesso et al., 2012), increasing average temperature (GoK, 2009; Yanda and Mubaya, 2011; IPCC, 2014), and changes in wind speed (Webster et al, 2005; Young et al., 2011) were also noted.

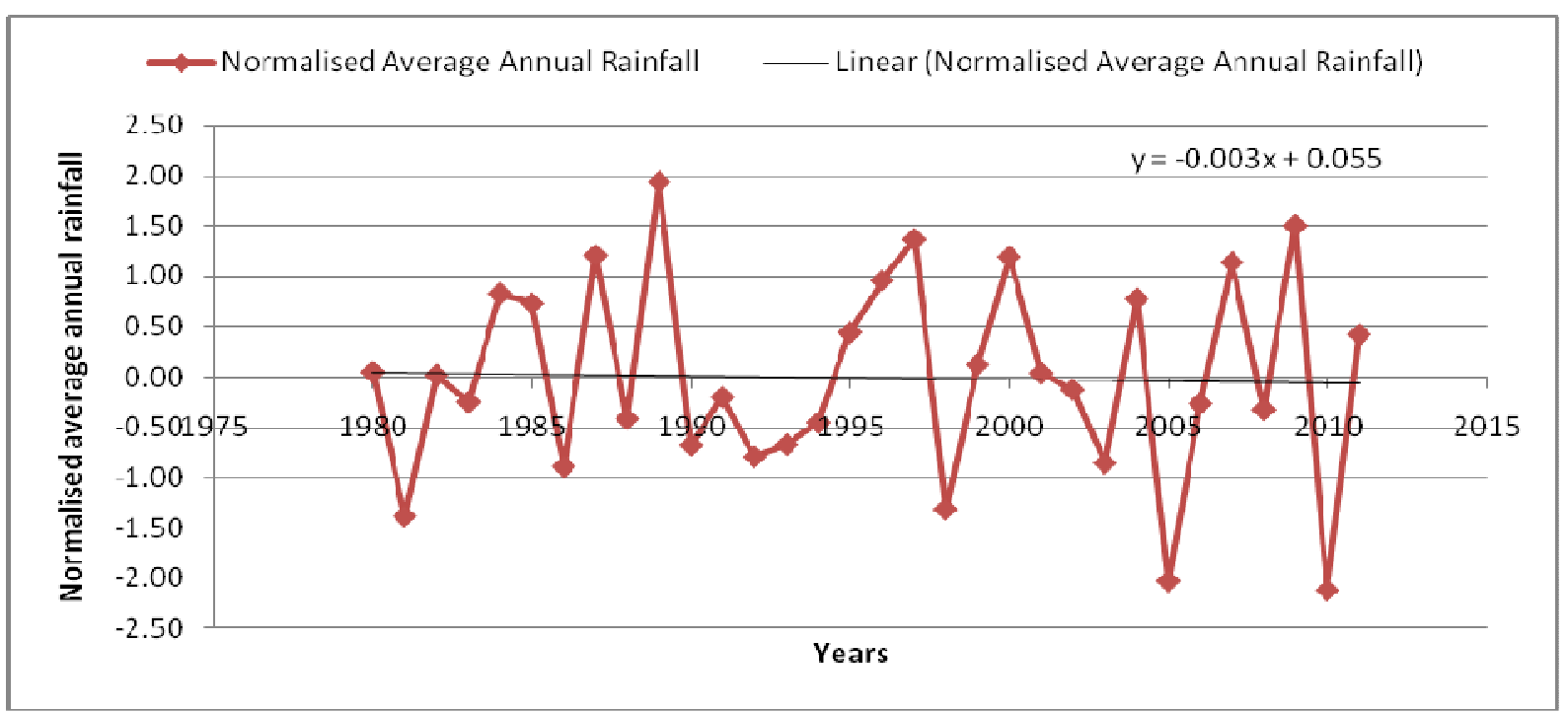

Source: TMA (2012)

Figure 1: Trend of annual rainfall (mm) from $1980-2011$ 
Ethiopian Journal of Environmental Studies and Management Vol. 8 no. 42015

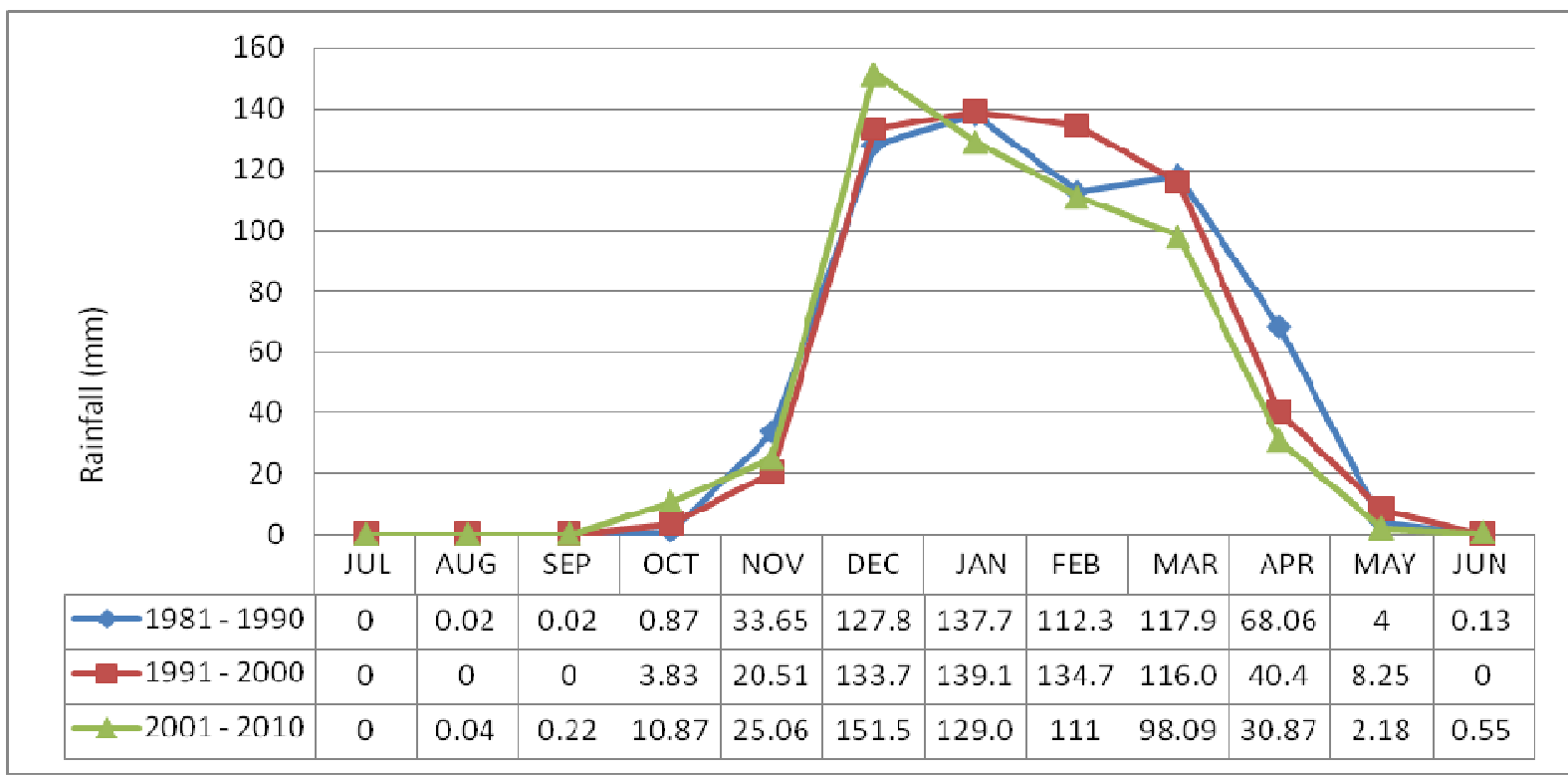

Source: TMA (2012)

Figure 2: Trends in monthly rainfall for three decades

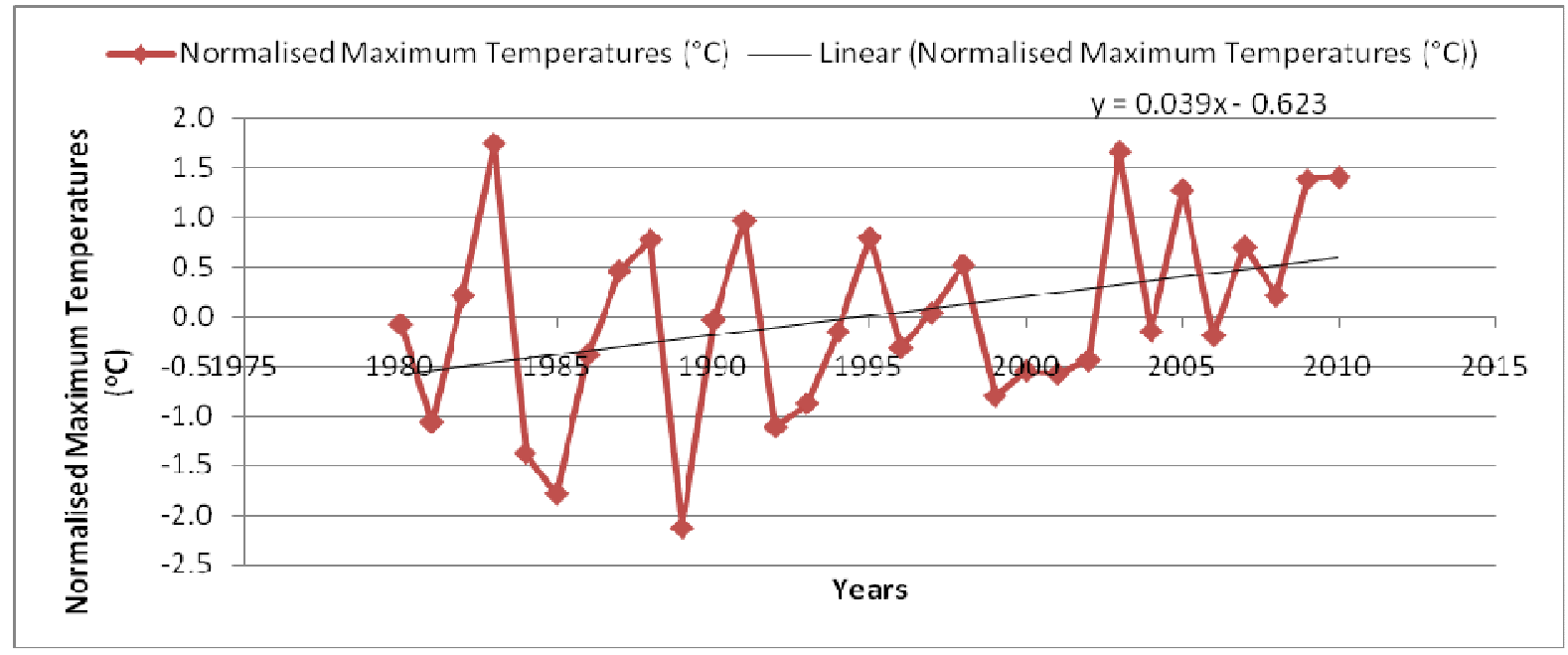

Source: TMA (2012)

Figure 3: Trend of mean annual maximum temperature $\left({ }^{\circ} \mathrm{C}\right)$ from $1980-2011$ 


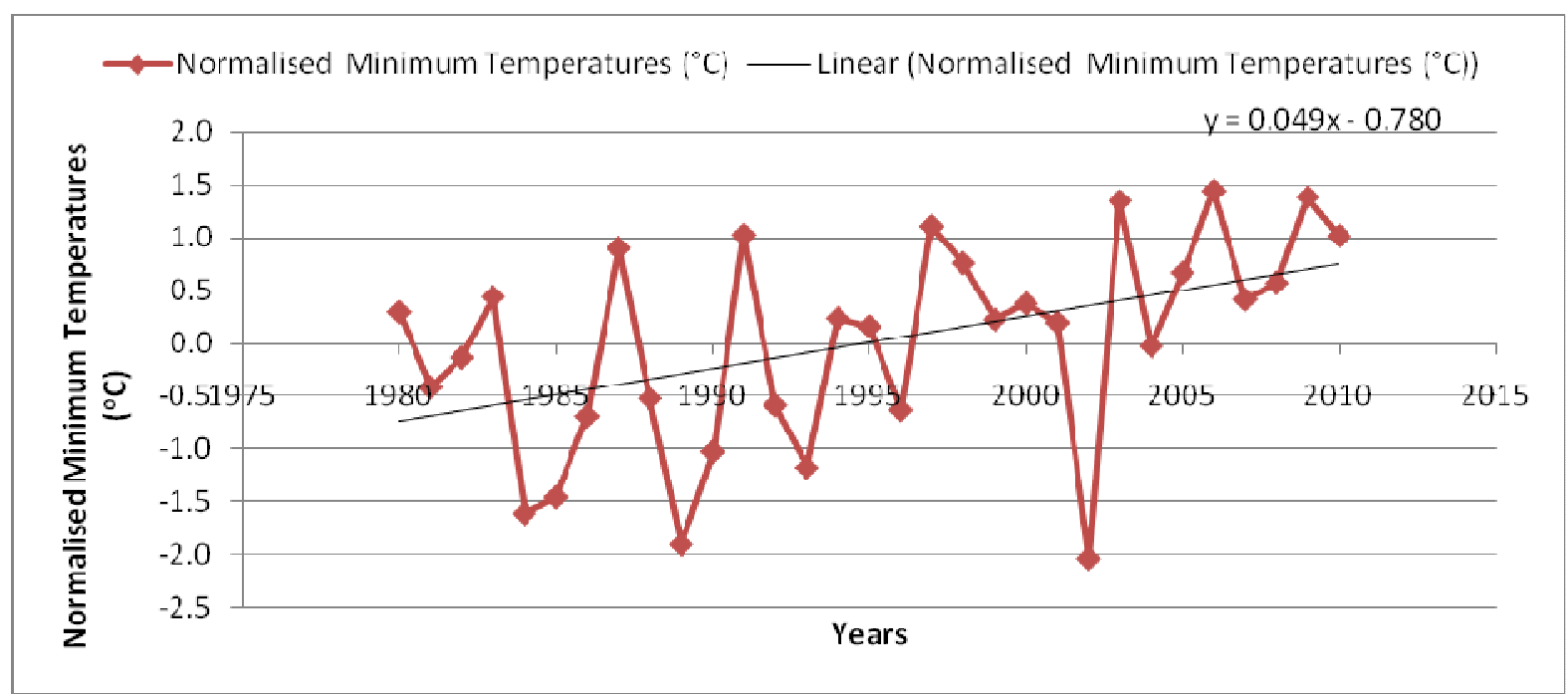

Source: TMA (2012)

Figure 4: Trend of mean annual maximum temperature $\left({ }^{\mathrm{O}} \mathrm{C}\right)$ from $1980-2011$

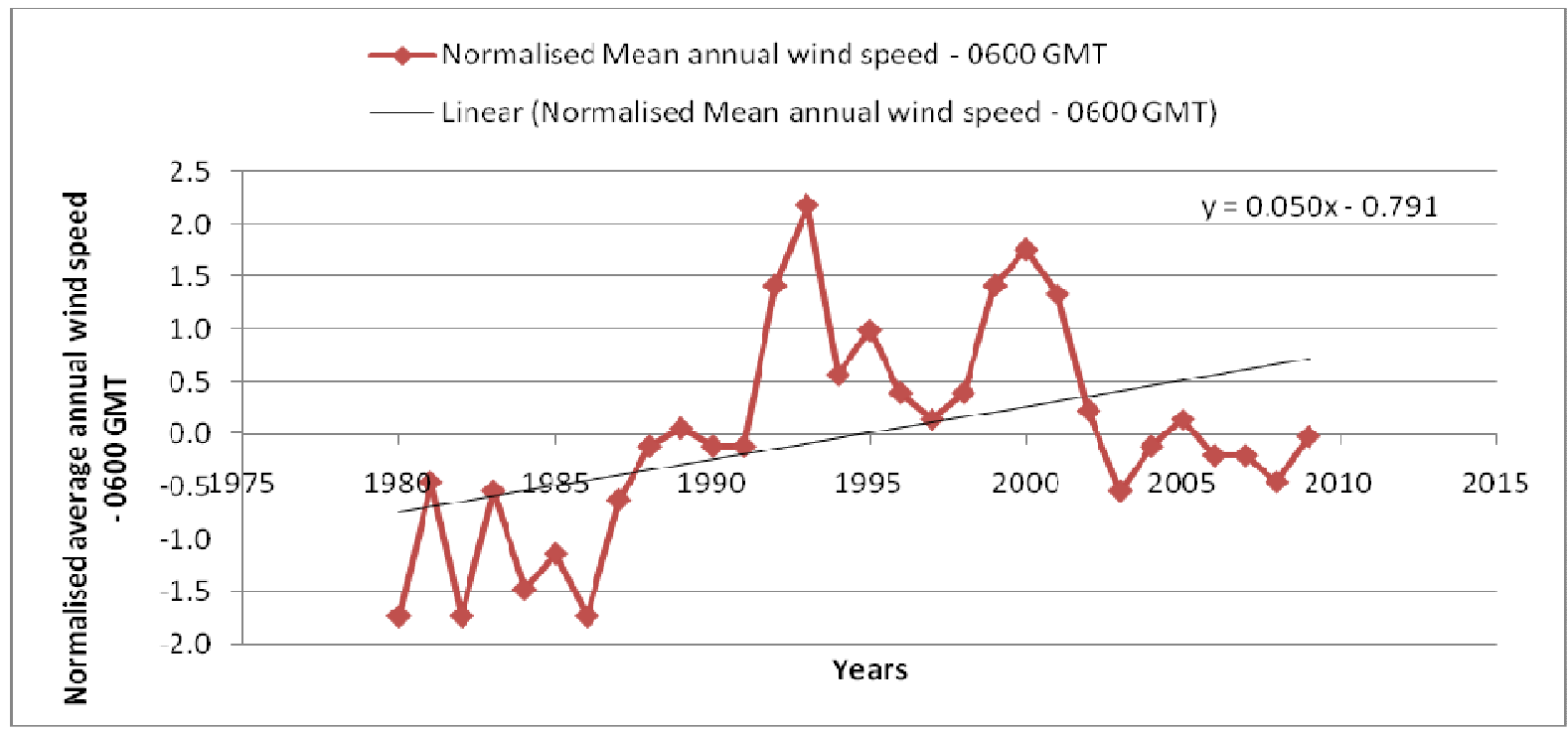

Source: TMA (2012)

Figure 5: Trend of wind speed (knots) recorded at 0600 GMT from 1980 to 2009 


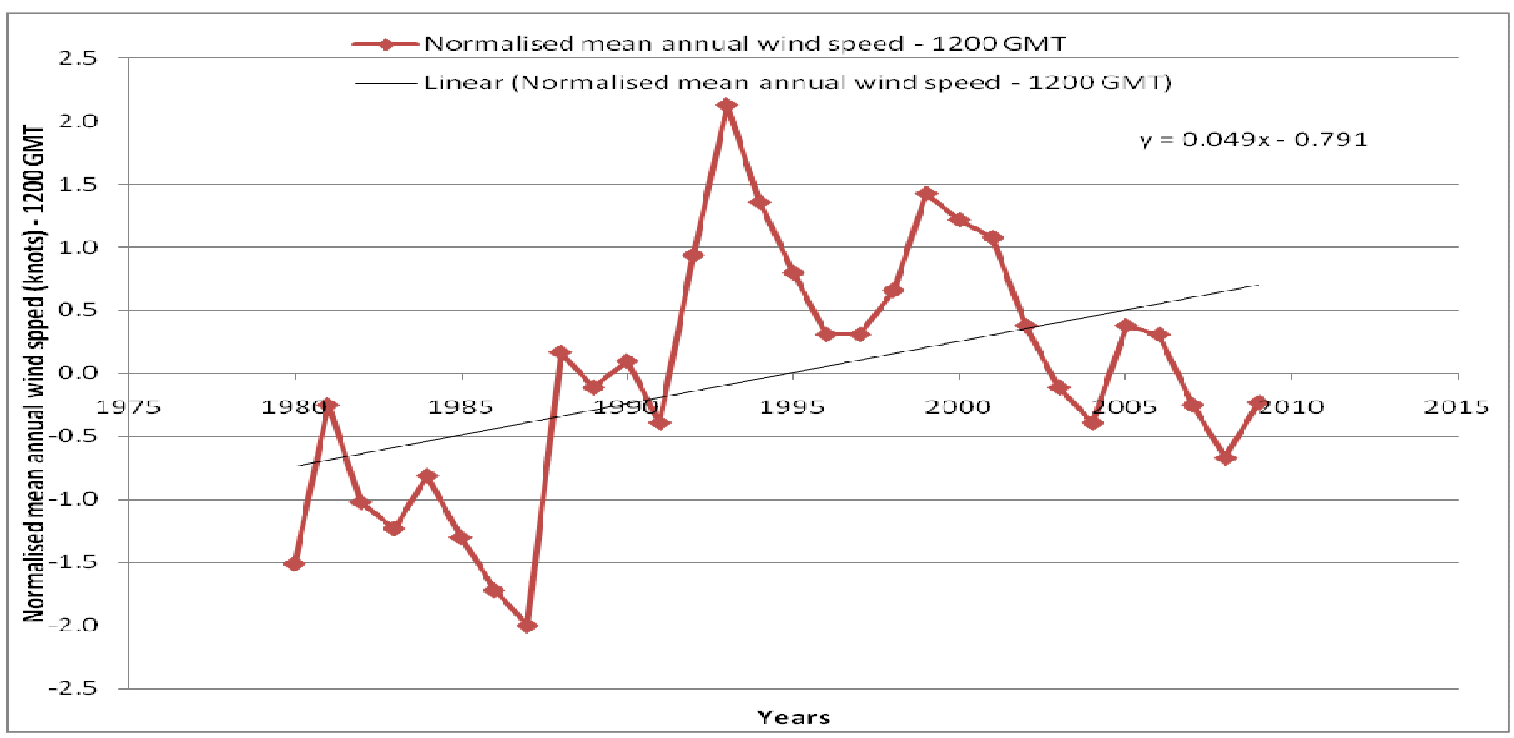

Source: TMA (2012)

Figure 6: Trend of wind speed (knots) recorded at 1200 GMT from 1980 to 2009

\section{Effects of Climatic Changes on Livelihood Activities and Sources}

The findings (Table 2) indicates the effects associated with climate changes to the livelihoods of people in Dodoma region. Based on the findings the key livelihood activities heavily impacted by climate change were crop farming and livestock keeping. However, these are the major livelihood activities that form the socio-economic base for the local communities. Crop and livestock farming accounts for $98.7 \%$ and $50.3 \%$ respectively of resident's occupations. Furthermore, climate change extreme events also affects the availability and productivity of critical livelihood resources including water, land, natural resources and pasture among others. Consequently, these affect agricultural productivity, planting season, settlements, socio-economic activities and local communities' income.

Table 2: Effects of climatic changes on livelihood activities within sex of respondents

\begin{tabular}{llcl}
\hline Effects of changes on livelihood activities & \multicolumn{2}{l}{$\begin{array}{l}\text { Responses } \\
\text { sex of respondents }(\mathrm{n}=398)\end{array}$} & \\
\cline { 2 - 3 } & Male & Female & \\
\hline Reduces agricultural productivity & $223(91.8)$ & $132(85.2)$ & $355(89.2)$ \\
Affects planting season & $208(85.6)$ & $123(79.4)$ & $331(83.2)$ \\
Reduces livestock pasture & $104(42.8)$ & $32(20.6)$ & $136(34.2)$ \\
Reduces water availability & $94(38.7)$ & $40(25.8)$ & $134(33.7)$ \\
Reduces income & $66(27.2)$ & $55(35.5)$ & $121(30.4)$ \\
Reduces the amount of land cultivated & $63(25.9)$ & $22(14.2)$ & $85(21.4)$ \\
Affects the number of livestock & $60(24.7)$ & $16(10.3)$ & $76(19.1)$ \\
Destruction of settlements & $39(16.0)$ & $30(19.4)$ & $69(17.3)$ \\
Reduces water availability for livestock & $26(10.7)$ & $24(15.5)$ & $50(12.6)$ \\
Affects socioeconomic activities & $18(7.4)$ & $19(12.3)$ & $37(9.3)$ \\
Destruction of crops & $16(6.6)$ & $15(9.7)$ & $31(7.8)$ \\
Leads to natural resources degradation & $13(5.3)$ & $14(9.0)$ & $27(6.8)$ \\
\hline
\end{tabular}

*Dataset based on multiple responses; values in parentheses are percentages 


\section{Manifestation of Climate Change Driven Impacts}

Further, an attempt was made to establish some of the manifestations of climate change driven impacts. This was done by examining the status of food and cash crops production overtime, loss of livelihood sources and effects experienced on livestock as a result of climatic related changes.

\section{Food and Cash Crop Production Overtime}

Regarding food crop production overtime, respondents were asked to indicate the status of food production from 2007 to 2011. The study findings revealed that in each of the five years more than $70 \%$ of households failed to produce adequate food crops. The proportion of households who produced enough food crops were $22.6 \%$ in $2007,25.6 \%$ in 2008 , $26.1 \%$ in $2009,27.6 \%$ in 2010 , and $25.1 \%$ in 2011. Given the findings, majority of households suffer from inadequate production of food crops and hence becoming vulnerable to challenges associated by food insecurity.

Further analysis using Chi-square $\left(\mathrm{x}^{2}\right)$ test for independence on the production status of food at household level in the cumulative past five years from 2007 to 2011 (Table 3) showed a significant association between the status in food production in relation to respondents district of residence; migration of some household members; assistance from various actors and institutions in assisting the local communities in adapting and mitigating climate change impacts. The Cramer's V statistics were 0.25 ; 0.18 ; and 0.27 respectively. In all cases, Cramer's V statistics were significant $(\mathrm{p}<0.05)$.

Table 3: Distribution of respondents by production of enough food at their household in the past five years $(2007 / 2011)(\mathrm{n}=398)$

\begin{tabular}{|c|c|c|c|c|c|c|c|c|}
\hline Variable & & $\begin{array}{l}\text { Produced } \\
\text { enough } \\
\text { food in all } \\
5 \text { yrs }\end{array}$ & $\begin{array}{l}\text { Did not } \\
\text { produce } \\
\text { enough } \\
\text { food in all } \\
5 \text { yrs }\end{array}$ & $\begin{array}{l}\text { Produced } \\
\text { enough } \\
\text { food in } \\
\text { some of } \\
5 \text { yrs }\end{array}$ & Total & $\begin{array}{l}x^{2} \\
\text { value }\end{array}$ & $d f$ & $\begin{array}{l}p \\
\text { value }\end{array}$ \\
\hline District & Bahi & $8(14.5)$ & $127(51.4)$ & $48(50.0)$ & $183(46.0)$ & 25.45 & 2 & 0.000 \\
\hline respondents & Kongwa & $47(85.5)$ & $120(48.6)$ & $48(50.0)$ & $215(54.0)$ & & & \\
\hline Sex of & Male & $34(61.8)$ & $150(60.7)$ & $59(61.5)$ & $243(61.1)$ & 0.03 & 2 & 0.985 \\
\hline respondents & Female & 21(38.2) & $97(39.3)$ & $37(38.5)$ & 155(38.9) & & & \\
\hline Organization & Member & $11(20.0)$ & $59(23.9)$ & $26(27.1)$ & $96(24.1)$ & 0.98 & 2 & 0.613 \\
\hline membership & $\begin{array}{l}\text { Not } \\
\text { member }\end{array}$ & $44(80.0)$ & $188(76.1)$ & $70(72.9)$ & $302(75.9)$ & & & \\
\hline Migration of & Migrated & $12(21.8)$ & $103(41.7)$ & $24(25.0)$ & $139(34.9)$ & 13.31 & 2 & 0.001 \\
\hline $\begin{array}{l}\text { some } \mathrm{HH} \\
\text { members }\end{array}$ & $\begin{array}{l}\text { Not } \\
\text { migrated }\end{array}$ & $43(78.2)$ & $144(58.3)$ & $72(65.1)$ & $259(65.1)$ & & & \\
\hline Assistance & Assisted & $45(81.8)$ & $102(41.3)$ & $50(52.1)$ & $197(49.5)$ & 29.89 & 2 & 0.000 \\
\hline $\begin{array}{l}\text { from actors / } \\
\text { institutions }\end{array}$ & Not Assisted & $10(18.2)$ & $145(58.7)$ & $46(47.9)$ & $201(50.5)$ & & & \\
\hline Extension & Supported & $37(67.3)$ & $145(58.7)$ & $59(61.5)$ & $241(60.6)$ & 1.43 & 2 & 0.490 \\
\hline $\begin{array}{l}\text { workers } \\
\text { support }\end{array}$ & $\begin{array}{l}\text { Not } \\
\text { supported }\end{array}$ & $18(32.7)$ & $102(41.3)$ & $37(38.5)$ & $157(39.4)$ & & & \\
\hline
\end{tabular}


The findings suggest for the need of undertaking strong measures in enhancing adequate production of food. Among such measures include diversification of agricultural and non agricultural activities, adoption of good agricultural practices, natural resources management, strengthening extension services and agricultural support systems, and use of irrigation techniques among others. Such assistance to the local community experiencing various climatic change vagaries can enhance their coping strategies (Page et al., 2010; Hoang et al., 2014; Milan and Ruano, 2014).

Regarding the production of cash crops in the study area, the findings revealed that the production of cash crops from 2007 to 2011 was very low as majority of residents (more than $70 \%$ in each year) failed to produce enough cash crops. Taking into consideration that the local communities in the study area depends on crop farming as the major source of income it is evident that failure to produce enough cash crops severely impacts the household economy and income levels.

\section{Loss of Livelihood Sources as a Result of Climatic Changes}

Climatic changes in Dodoma region has also led to the loss of household livelihood sources. This phenomenon was identified by 164 respondents who have already experienced the loss. Among the livelihood resources lost include agricultural land, crops, water sources, forest, livestock and pastureland (Table 4). Other livelihoods effects caused by climatic related hazards in the area were loss of income spent on purchasing agricultural inputs and labour hiring following crop failure and poor performance of entrepreneurial activities such as businesses as a way of diversifying household's income generating activities.

Furthermore, a chi-square test for independence was undertaken to determine whether there is an association between household status on loss of livelihood sources and district of residence in relation to sex of respondents. The findings (Table 5) indicate that there was a significant relationship between household's loss of livelihood sources and respondents districts of residence in which most households in Bahi district had lost livelihood sources compared to households in Kongwa district. In this case, the $P h i$ statistic value was $0.324(P<0.05)$. This is explained by the fact that Kongwa district is strategically located close to agricultural and livestock research institutions hence benefiting from extension services provided by the institutions. In addition, Kongwa District has many town centres such as Mbande, Kibaigwa and Kongwa all equipped with good business infrastructures hence capable of buffering the impacts of climate change hazards as compared to their counterparts in Bahi district.

Table 4: Distribution of respondents based on type of livelihood resource lost $(n=164)$

\begin{tabular}{lll}
\hline Type of livelihood resource lost & $\mathrm{N}$ & Percent* \\
\hline Agricultural land & 136 & 82.9 \\
Crops & 105 & 64.0 \\
Water sources & 90 & 54.9 \\
Forest & 83 & 50.6 \\
Livestock & 60 & 36.6 \\
Pastureland & 58 & 35.4 \\
\hline
\end{tabular}

*Dataset based on multiple responses 
Table 5: Distribution of respondents based on loss of household livelihood sources $(n=398)$

\begin{tabular}{|c|c|c|c|c|c|c|c|}
\hline \multirow[t]{2}{*}{ Variables } & & \multicolumn{2}{|c|}{$\begin{array}{l}\mathrm{HH} \text { status on loss } \mathrm{o} \\
\text { livelihood sources }\end{array}$} & \multirow[t]{2}{*}{ Total } & \multirow[t]{2}{*}{$\begin{array}{l}x^{2} \\
\text { value }\end{array}$} & \multirow[t]{2}{*}{$d f$} & \multirow[t]{2}{*}{$\begin{array}{l}p \\
\text { value }\end{array}$} \\
\hline & & Lost & Not lost & & & & \\
\hline \multirow[t]{2}{*}{ District of residence } & Bahi & $107(65.2)$ & $76(32.5)$ & $183(46.0)$ & 41.68 & 1 & 0.000 \\
\hline & Kongwa & $57(34.8)$ & $158(67.5)$ & $215(54.0)$ & & & \\
\hline \multirow[t]{2}{*}{ Sex of respondents } & Male & $106(64.6)$ & $137(58.5)$ & $243(61.1)$ & 1.50 & 1 & 0.220 \\
\hline & female & $58(35.4)$ & $97(41.5)$ & 155 (38.9) & & & \\
\hline
\end{tabular}

Numbers in parentheses are percentages

\section{Effects Experienced on Livestock as a Result of Climatic Changes}

An attempt was also made to establish the effects experienced by the local community on feeding their animals as a result of climatic changes. The findings (dataset based on multiple responses, $\mathrm{n}=$ $307)$ indicated that the major effects on feeding livestock were long distance trekking on search for pasture $(67.8 \%)$, dwindling of pasture areas $(63.2 \%)$, and death of animals $(57.7 \%)$. Other challenges were long distance trekking in search for water (46.6\%), drying of water sources $(36.8 \%)$, temporary migration of animals (27.4\%), and others (2.0\%) such as overgrazing. These results were further ascertained during FGDs, where it was also revealed that climate change in the area has led to the loss of livestock due to deaths caused by lack of pasture and water.

Given the findings, the key challenges caused by climatic changes related impacts on feeding livestock in Dodoma region are the loss of pasture and water for livestock. Consequently, the decline in pasture and water for livestock has led to serious threats to livestock keepers in the region. Therefore, there is a need for assisting local residents to better adapt to the impacts of climate change in the form of awareness creation, genetic improvement of local livestock breeds, construction dams and cattle watering points, and proper land use planning.

\section{Difficulties in feeding Household Member Overtime}

Respondents were also asked to determine whether they have experienced difficulties in feeding their household members as a result of climate change. The findings indicated that majority of households have experienced difficulties in feeding their household members over time. For instance, in the past five (5) years (2007 - 2011), more that $60 \%$ of households have experienced difficulties in feeding their household members. The situation was more severe in February whereby about 81.1 - 94.8 percent of households experienced such difficulties. As a response, households used strategies such as reducing the number of meals, purchase of food, selling of livestock, reducing household consumption, relief food, and diversification of income generating activities. Other strategies used were temporary migration, charcoal selling, borrowing grains and money, change cropping patterns, begging, remittance from relatives, selling of household assets and mortgage.

Nevertheless, the sustainability of some adaptation strategies such as migration is questionable as they can lead to negative social, economic and environmental consequences as noted during FGDs. This poses a challenge for climate change actors in developing sustainable and inclusive approach in dealing with climate change challenges especially the issue of food security across different levels and social 
groups. The findings on difficulties in feeding household members in Dodoma region as a result of climate change are in tandem with the findings from other studies in Tanzania (Mongi et al., 2010; Afifi et $a l ., 2014)$. Experience from Kenya and Ghana also shows food insecurity challenges resulting from extreme climate change events, the coping strategies used by the local communities in surviving the wrath of climate change vagaries and the associated challenges for some of coping mechanisms (Songok et al., 2011; Rademacher-Schulz et al., 2014; Warner and Afifi, 2014).

\section{Conclusion and Recommendations}

The analysis of community views have indicated decrease in rainfall, rainfall unpredictability and droughts all of which are related to decrease in rainfall amount; temperature increase and more intense storms as major climatic changes in the area. This was further confirmed through the analysis of meteorological data in the study area that further established changing trends in the amount of rainfall, temperature and wind speed overtime. It was further established that, the effects of climate change in Dodoma region include reduced agricultural productivity, alteration of the planting season, reduced pasture for livestock, reduced water availability and reduced household income among others. This suggests that the key livelihood activities heavily impacted by climate change were crop farming, livestock keeping and non agricultural activities.

Given the findings, this article suggests that climate change policies, strategies and actors initiatives at local level should focus on addressing the challenges on water availability for domestic and agricultural use, agricultural productivity, pasture availability for livestock through sustainable livestock keeping and land use planning, promotion of socio-economic activities including diversification of income generating activities, and promotion of natural resources management. Such efforts should be complimented by resolving local level conflicts among competing interests over utilization of productive resources. In this regard, land use planning and enforcement are critical parameters in controlling the problem of natural resource degradation among resource users of which for the case of Dodoma region are dominated by farmers and livestock keepers.

\section{Acknowledgement}

The authors acknowledge the financial support and supervision of the research project from the Institute of Rural Development Planning (Dodoma, Tanzania) and the University of Eldoret (Eldoret, Kenya) respectively. The authors are also grateful to the Regional Administrative Secretary - Dodoma Region; Directors of Bahi and Kongwa District Councils; and all respondents in Dodoma region for their logistical support and cooperation during the study.

\section{References}

Afifi, T., Liwenga, E. and Kwezi, L. (2014). Rainfall-induced crop failure, food insecurity and outmigration in Same-Kilimanjaro, Tanzania, Climate and Development, 6(1): 53-60.

Global Humanitarian Forum (2009) The Anatomy of a Silent Crisis. Geneva, Switzerland: Global Humanitarian Forum

Government of Kenya (GoK) (2009). State of Environment Report Kenya, 2006/7: Effects of climate change and coping mechanisms in Kenya. National Environmental Management Authority (NEMA), Kenya. 
Hoang, M.H., Namirembe, S., van Noordwijk, M., Catacutan, D., Öborn, I., Perez-Teran, A. S., Nguyen, H.Q. and Dumas-Johansen, M.K. (2014). Farmer portfolios, strategic diversity management and climate-change adaptation - implications for policy in Vietnam and Kenya. Climate and Development, 10.1080/17565529.2013.857588

IPCC (2014). Climate Change 2014: Impacts, Adaptation, and Vulnerability. Part A: Global and Sectoral Aspects. Contribution of Working Group II to the Fifth Assessment Report of the Intergovernmental Panel on Climate Change. Cambridge University Press, Cambridge, United Kingdom and New York, NY, USA, XXX pp.

Koch, I.C., Vogel, C. and Patel, Z. (2007). Institutional Dynamics and Climate Change Adaptation in South Africa. Mitigation and Adaptation Strategies for Global Change 12: 1323 - 1339.

Kothari, C.R. (2004). Research Methodology - Methods and Techniques. Second Revised Version. New Age International Publishers.

Mearns, R. and Andrew N. (2010). Equity and vulnerability in a warming world: An introduction and overview. In: Mearns, R. and Andrew, N. (Eds) (2010): Social Dimensions of Climate Change: Equity and vulnerability in a warming world. The World Bank, Washington DC.

Measham, T.G., Preston, B.L., Smith T.F., Brook C., Gorddard R., Withycombe G. and Morrison, C. (2011). Adapting to climate change through local municipal planning: Barriers and challenges. Mitigation and Adaptation Strategies for Global Change 16: 889 - 909.
Milan, A. and Ruano, S. (2014). Rainfall variability, food insecurity and migration in Cabricán, Guatemala. Climate and Development, 6(1): 6168.

Mongi, H., Majule, A.E. and Lyimo, J.G. (2010). Vulnerability and adaptation of rainfed agriculture to climate change and variability in semi-arid Tanzania. African Journal of Environmental Science and Technology, 4(6): 371 - 381.

Mudelsee, M. (2010). Climate time series analysis: Classical statistical and Bootstrap methods (Vol. 42). Springer.

NIDOS (2009). Climate Change Fact Sheet. Network of International Development Organizations in Scotland. www.nidos.org.uk July 2009

Okoba, B., Dejene, A.A. and Mallo, M. (2011). Climate shocks, perceptions and coping options in semi-arid Kenya, pp 167 - 181. In Filho, W. L. (ed.) (2011). Experiences of Climate Change Adaptation in Africa, Climate Change Management. SpringerVerlag Berlin Heidelberg.

Page, S.L.J., Karanja, D.K., Mbwaga, A. M., Letayo, E.A.S. and Nsemwa, L.T.H. (2010). The underlying cause of the 2009 sorghum failure in Kongwa district and its implication for Tanzania's vulnerability to climate change. Food Sec. 2:157167.

Rademacher-Schulz, C., Schraven, B. and Mahama, E. S. (2014). Time matters: shifting seasonal migration in Northern Ghana in response to rainfall variability and food insecurity. Climate and Development, $6: 1: 46-52$.

Sewando, T.P. and Yohana, M. (2012). Adaptation and coping mechanisms to 
climate change variability in pastoral system in Tanzania. Journal of Environmental Extension, 10: 30-35.

Songok, C.K., Kipkorir, E.C. and Mugalavai, E.M. (2011). Integration of indigenous knowledge systems into climate change adaptation and enhancing food security in Nandi and Keiyo District, Kenya, pp 69 - 95. In Filho, W. L. (ed.) (2011). Experiences of Climate Change Adaptation in Africa, Climate Change Management. Springer- Verlag Berlin Heidelberg.

Tanzania Meteorological Agency (TMA) (2012). Rainfall, temperature and wind speed data for Dodoma region for the years 1980 - 2011, Dodoma, TMA.

Tesso, G., Emana, B. and Ketema, M. (2012). A time series analysis of climate variability and its impacts on food production in North Shewa zone in Ethiopia. African Crop Science Journal, 20(supplement S2): 261 274.

URT (2006). National Adaptation Programme of Action (NAPA) for Tanzania. Division of environment, Dar es salaam, Tanzania.

URT (2008). State of the Environment Report - 2008. Vice President's Office, Division of Environment, United Republic of Tanzania, Dar es salaam.

URT (2010a). Regions profile. http://www.tanzania.go.tz/regions/dod oma/profile.htm Accessed on 28/11/2010
URT (2010b): Bahi district socio-economic profile. Jointly prepared by IRDP and Kongwa District Council.

URT (2013). 2012 Population and Housing Census: Population Distribution by Administrative areas. Dar-es-Salaam, Tanzania.

Warner, K. and Afifi, T. (2014). Where the rain falls: Evidence from 8 countries on how vulnerable households use migration to manage the risk of rainfall variability and food insecurity. Climate and Development, 6:1, 1-17.

Webster, P.J., Holland, G.J., Curry, J.A. and Chang, H.R. (2005). Changes in tropical cyclone number, duration, and intensity in a warming environment. Science, 309(5742): 1844-1846.

Witt, G. (2013). Using data from climate science to teach introductory statistics. Journal of Statistics Education, 21(1): 1 -23.

World Bank (2010). World Development Report 2010: Development and Climate Change. The International Bank for Reconstruction and development. The World Bank, Washington DC.

Yanda, P.Z. and Mubaya, C.P. (2011). Managing climate change in Africa: Local level vulnerabilities and adaptation experiences. Mkuki na Nyota Publishers 1td, Dar es Salaam, Tanzania.

Young, I. R., Zieger, S., and Babanin, A.V. (2011). Global trends in wind speed and wave height. Science, 332(6028), 451-455. 